\title{
Personality Traits and Severity of Wife Abuse among Iranian Women
}

\author{
Seyed Mehdi Motevaliyan ${ }^{1}$, Siti Nor Yaacob ${ }^{2}$, Rumaya Juhari ${ }^{2}$, Mariani Mansor ${ }^{2} \&$ Mahmood Baratvand $^{3}$ \\ ${ }^{1}$ Faculty of Human Ecology, Universiti Putra Malaysia, Serdang, Malaysia \\ ${ }^{2}$ Family, Adolescent and Child Research Center of Excellent (FACE), Universiti Putra Malaysia, Serdang, \\ Malaysia \\ ${ }^{3}$ Faculty of Education, Universiti Putra Malaysia, Serdang, Malaysia \\ Correspondence: Seyed Mehdi Motevaliyan, Faculty of Human Ecology, Universiti Putra Malaysia 43400 UPM \\ Serdang, Selangor, Malaysia. Tel: 60-1-7332-5103. E-mail: mehdimotevaliyan@yahoo.com
}

\author{
Received: September 27, 2013 Accepted: January 23, 2014 Online Published: March 31, 2014 \\ doi:10.5539/ass.v10n7p234 \\ URL: http://dx.doi.org/10.5539/ass.v10n7p234
}

\begin{abstract}
The main purpose of this study was to determine the relationships between personality traits and severity of wife abuse among Iranian women in Tehran city in Iran. The study involved 398 women who sought treatment at 4 selected hospitals by using multistage stratified sampling technique. Conflict Tactic Scale (CTS2) and Five-Factor Personality Inventory (NEO-FFI) were used to measure severity of wife abuse and personality traits respectively.

Findings showed that out of 398 women studied, $42.5 \%$ received minor abuse and $43.5 \%$ received severe abuse. Severity of total wife abuse was positively related to neuroticism personality and negatively related to extraversion, agreeableness and conscientiousness. However, no significant relationship was note for total wife abuse and openness personality. The result of multinomial logistic regression indicated that neuroticism personality trait was a significant predictor of minor and severe total abuse. The results of the current study highlighted the importance of personality traits in explaining the severity of wife abuse in Tehran, Iran. Therefore, strategies to prevent and intervene cases of abuse among wives in Tehran, Iran should take into consideration individual's personality traits.
\end{abstract}

Keywords: wife abuse, personality, CTS2, NEO-FFI

\section{Introduction}

For some people, family is a place of hope, love and support; for others, it is paradoxical mixture of aggression and tenderness (Bengtson, Acock, Allen, Anderson, \& Klein, 2005). Home should be the safest place for a woman and the husband should be her best protector. However, for some women home is the most dangerous place for them, and husbands are found to be the main abuser (Wiehe, 1998).

Wife abuse refers to violence against wife or wife battering (Oladeji \& Adegoke, 2008; Records, 2007; Thabet, Tawahina, Sarraj, \& Vostanis, 2011). Wife abuse occurs in different forms such as physical, sexual, psychological, fiscal, and social (Ezazi, 2002; Hegarty, Hindmarsh, \& Gelles, 2000; Records, 2007). Wife abuse is a social problem in the world (Alio, Nana, \& Salihu, 2009; Tokuc, Ekuklu, \& Avcioglu, 2010); for instance, there were over 102,500 victims of intimate abuse in Canada in 2010 (Sinha, 2012). Nagae and Dancy (2010) reported physical, psychological and sexual abuse among women in Japan. Walby and Allen (2004) stated that 54\% of rapes against women in England were committed by their partners or ex-partners; and there were also more than 1,300 calls of daily domestic violence against women. However, the police estimated that calls are just $23 \%$ of all cases of domestic violence, because most of the victims do not report the incidents (Walby \& Allen (2004). Ludermir et al. (2008) showed that a substantial number of women in Brazil experience physical abuse $(10 \%$ to $56 \%$ ) and sexual abuse $(10 \%$ to $30 \%)$ at least once during their lifetime.

The level and rate of wife abuse in less developed countries is higher compared to developed countries (Ahmadi \& Alimardi, 2005; Faqir, 2001). For example, a study by Ruikar and Pratinidhi (2008) in India reported the rate of wife abuse was $61.5 \%$. In a different study, Haj-Yahya (1999) noted that Palestinian women faced higher levels of psychological, sexual, physical, and economical abuse. A national study by Ghazitabatabayi et al. (2005) revealed that $66 \%$ of Iranian women have been abused by their husbands from the beginning of their married life. A study 
by Nohjah et al. (2011) found that the rates of psychological, physical and sexual wife abuse in Iran are $41 \%$, $20.2 \%$ and $10.93 \%$ respectively.

Wife abuse has negative effect on women, their families, and consequently the whole society (Kyu \& Kania, 2005). Setarefrouzan, Dejman, and Baradaraneftekhari (2006) found that $18 \%$ of women referred to Tehran legal medicine centers suffered from wife abuse which in turn increased financial cost to them, family and also society.

The negative effects include negative attitude toward marriage, depression, suicide, addiction, social isolation, child battering, retaliatory violence, increase extramarital sex and loss of interest in sex, poor psychological and emotional well-being, low self-esteem, stress, and psychosomatic disorders (Hampton \& Gullotta, 1993), chronic fatigue and tension, intense startle, disturbed sleep, have a bad eating pattern, nightmares, self-blame, physical injury and death (Ezazi, 2002). Abuse also can have negative influence on the women's job (Ashouri \& Moazami, 2001; Kyu \& Kania, 2005; Wiehe, 1998).

Abuse incurs financial and time cost to wives, families, and governments. In Canada, government spent about $\$ 1.3$ billion for intimate violence in 1992 (Ferris, McMain, \& Silver, 1997). In the U.S., government spent 3 to 5 billion dollars annually for intimate violence (Crandall, Schwab, Sheehan, \& Esposito, 2009). According to learning theory, abusive behavior is learned. Thus, children who live in an abusive family may learn to do or become victims of abuse during their adulthood.

The consequences of wife abuse are related to its severity (Belfrage \& Rying, 2004; Mignon, Larson, \& Holmaes, 2002). The more severe the abuse, the more negative effects will be imposed on the women's psychological and physical health (Records, 2007). Fakhari et al. (2011) in a study among 600 women who visited the health center in Tabriz (Iran) showed that $5.5 \%$ of the respondents had experienced the blue or black bruises on the eyes due to abuse during their marriage time, and 3.3\% experienced during the last year, and 3\% of them visit a doctor because of the injuries. About $1 \%$ of the respondents reported broken hand/leg or ear injury. Kaldi, Hajbabayi and Kiyanfard (2005) interviewed 50 incarcerated women and men who killed their spouse. Results showed that for both genders, wife abuse was the main reason of the crime. Men were incarcerated due to severity of abuse and for the women, the act was to stop the husbands from abusing them.

Women's characteristics may also affect the level or severity of the abuse. Women's personality is perceived as one of the significant factors that determine their behavior, such as stay with abuser husband and being exposed to more abuse or leave them (Shoultes, 2008). Women with certain personality traits may try to seek help to decrease the severity of abuse (Panaghi, Pirouzi, Shirinbayan, \& Ahmadabadi, 2011). Narimani and Aghamohamadian (2005) stated that introversion/extraversion dimensions of personality may relate to abuse while psychological aggression may lead to neuroticism (Burton, Hafetz, \& Henninger, 2007; Rampersad, 2008).

Personality trait approach pays attention to differences between individuals as well as identifying and measuring individual's personality characteristics (Mischel, Shoda, \& Smith, 2003). Traits are defined as routine patterns of emotion, thought, and behavior (Kassin, 2003), in relation to one's acceptance of minor or severe wife abuse. In other word, personality traits are the most important factor of people's adaptation (Hayes \& Joseph, 2003).

Talbot, Duberstein, King, Cox, and Giles (2000) showed that there is a significant relationship between dimensions of personality and child abuse. Colémont, Hiel, and Cornelis (2011) showed that personality traits is related to punitive attitude and based on this attitude, women think they deserve to be abused. Sharma (2011) showed that neuroticism did not have significant relationship with wife abuse. However, extraversion had significant positive relationship with verbal and physical wife abuse, while openness had significant negative relationship with wife abuse. She also found that agreeableness personality had significant positive relationship with physical and sexual wife abuse, while conscientiousness had positive relationship with verbal abuse.

Panaghi et al. (2011) reported a positive relationship between neuroticism and psychological, physical, and sexual abuse among women in Kermanshah (Iran). The result of the study by Panaghi et al. showed that extraversion had negative relationship with psychological, physical, and sexual abuse. Conscientiousness had negative relationship with psychological and sexual abuse. Neuroticism was a strong predictor for physical and psychological wife abuse and conscientiousness was a strong predictor for sexual abuse. Rampersad (2008) showed that there is a significant relationship between psychological aggression, neuroticism, and social support. Study by Vittengl, Kraft and Jarrett (2003) and Sharma (2011) showed that five dimensions of personality are important elements among women which in turn are related to severity of wife abuse.

\section{Methodology}

\subsection{Population and Sample}

The population of this study was all women who sought treatment in 4 hospitals in Tehran due to medical problems. 
Respondents were selected by using a multistage stratified sampling technique. A total of 398 women were selected as the respondents of the study.

\subsection{Instruments}

Conflict Tactic Scale: CTS2 scale was developed by Straus, Hamby, Boney-Mccoy and Sugarman (1996). This scale has 78 items that measured five dimensions which are negotiation (6 items), injury (6 items), psychological ( 8 items), physical (12 items), and sexual ( 7 items) as well as wife abuse (total score). Half of the items measure the wife's behavior and the rest belongs to the husband's behavior against wife. In this study, researcher excluded the husband's behavior as well as the negotiation dimension from the scale. Acceptable validity of the instrument was reported by Straus, Hamby, and Warren (2003) and Sharma (2011). Hemati (2005) showed that CTS2 has good reliability coefficient (Cronbach's Alpha $=.78$ ), and Pournaghashtehrani (2006) reported Cronbach's Alpha of .92 among Iranian respondents. The reliability of the scale for the current study was good (Cronbach's Alpha $=.86$ ).

The Five-Factor Personality Inventory (NEO-FFI): The NEO-FFI is a short form of five factors personality scale that developed by Costa and McCrae in 1983 (John \& Srivastava, 1999). It has 60 items with a 5-point Likert options ranging from 1 "strongly disagree" to 5 "strongly agree". Garousifarshi and Soufiyani (2008) showed acceptable reliability of NEO-FFI among Iranian in their study (Cronbach's Alpha $=.86$ ). the reliability of the NEO-FFI in the current study was acceptable (Cronbach's Alpha $=.71$ ).

\section{Results}

\subsection{Descriptive Findings}

Respondents were between 18 and 64 years $(M=32.5, \mathrm{SD}=8.39)$. Majority of the respondents was in the age category of 26 to 31 years (31.7\%) follows by the category of 32 to $37(25.1 \%)$. Most of the respondents had education at college level (38.4\%), which is followed by Bachelor level (33.2\%). Majority of the respondents was housewives (62.6\%). Length of marriage among respondents was between 1 and 52 years $(\mathrm{M}=10.71, \mathrm{SD}=8.8)$. More than one third of the respondents had been married between 1 and 5 years (37.4\%). More than half of the respondents (54.7\%) had 1 to 2 children, while $31.2 \%$ had no children.

Based on Table 1, majority (85.9\%) of the respondents experienced at least one type of wife abuse during the last year. Only 56 respondents $(14.1 \%)$ did not experience any types of wife abuse. Majority $(63.58 \%)$ of the respondents obtained abuse score between 1 and 50, and about half of the respondents (48.50\%) reported abuse score between 1 and 25 .

Table 1. Distribution of total abuse score among respondents $(\mathrm{N}=398)$

\begin{tabular}{lll}
\hline Score & $\mathbf{n}$ & $\mathbf{\%}$ \\
\hline No abuse & 56 & 14.1 \\
Score $1-50$ & 253 & 63.58 \\
Score $51-100$ & 38 & 9.55 \\
Score $101-150$ & 22 & 5.53 \\
Score $151-200$ & 9 & 2.26 \\
Score $201-250$ & 6 & 1.50 \\
Score 251 and more & 14 & 3.52 \\
Mean=44.48; SD=82.42 & & \\
Minimum=0; Maximum $=650$ & & \\
\hline
\end{tabular}

Based on Table 2, the mean for neuroticism was $34(\mathrm{SD}=7.0)$. Based on this mean score of neuroticism, $51.8 \%$ of the respondents had low neuroticism score. The mean for extraversion was $39(\mathrm{SD}=6.0)$ and $58 \%$ of the respondents had high extraversion score. The indexes for openness were $\mathrm{M}=38$ and $\mathrm{SD}=4.0$, and based on the mean scores, $51.8 \%$ and $47.9 \%$ of the respondents were categorized as low and high openness respectively. The indexes for agreeableness were $\mathrm{M}=44$ and $\mathrm{SD}=5$, and $51.8 \%$ of the respondents was classified as high in agreeableness. For conscientiousness, the index was $\mathrm{M}=46$ and $\mathrm{SD}=6.0$, and $45.4 \%$ of the respondents were in the low category.

Table 2. Distribution of respondents by personality scores $(\mathrm{N}=398)$ 


\begin{tabular}{|c|c|c|c|c|c|}
\hline \multirow{5}{*}{ Neuroticism } & & Mean & SD & $\mathbf{n}$ & $\%$ \\
\hline & & 34 & 7.6 & & \\
\hline & Low & & & 206 & 51.8 \\
\hline & High & & & 189 & 47.5 \\
\hline & No response & & & 3 & .7 \\
\hline \multirow[t]{4}{*}{ Extraversion } & & 40 & 6.0 & & \\
\hline & Low & & & 165 & 42.0 \\
\hline & High & & & 231 & 58.0 \\
\hline & No response & & & 2 & .5 \\
\hline \multirow[t]{4}{*}{ Openness } & & 38 & 5.0 & & \\
\hline & Low & & & 206 & 51.8 \\
\hline & High & & & 191 & 47.9 \\
\hline & No response & & & 1 & .3 \\
\hline \multirow[t]{4}{*}{ Agreeableness } & & 44 & 6.0 & & \\
\hline & Low & & & 206 & 51.8 \\
\hline & High & & & 190 & 47.7 \\
\hline & No response & & & 2 & .5 \\
\hline \multirow[t]{4}{*}{ Conscientiousnes } & & 47 & 7.0 & & \\
\hline & Low & & & 181 & 45.4 \\
\hline & High & & & 215 & 54.02 \\
\hline & No response & & & 2 & .5 \\
\hline
\end{tabular}

\subsection{Inferential Findings}

Table 3, reveals that four of five personality traits was significantly related to total wife abuse. The significant relationship was found for neuroticism, extraversion, agreeableness and conscientiousness. The result showed that respondents with high score on neuroticism experienced more abuse $\left(T_{s}=.3, p<.0001\right)$. Wives who were extravert, agreeable, and conscientious tend to experience less abuse. Openness personality trait did not indicate significant correlation with severity of wife abuse.

Table 3. Relationship between personality and severity of wife abuse $(\mathrm{N}=398)$

\begin{tabular}{lllllllllll}
\hline Personalities & \multicolumn{2}{l}{ Neuroticism } & \multicolumn{2}{l}{ Extraversion } & \multicolumn{2}{l}{ Openness } & \multicolumn{2}{l}{ Agreeableness } & \multicolumn{2}{c}{ Conscientiousness } \\
\hline & $r_{s}$ & $p$ & $r_{s}$ & $p$ & $r_{s}$ & $p$ & $T_{s}$ & $p$ & $r_{s}$ & $p$ \\
Total abuse & .30 & .00 & -.16 & .00 & .00 & .98 & -.165 & .00 & -.168 & .00 \\
\hline
\end{tabular}

A multinomial logistic regression analysis was performed to determine the unique predictors of severity of total wife abuse. Based on Straus and Douglas (2004), severity of wife abuse was divided to three categories which are non-abused, minor abuse, and severe abuse. Non-abuse category was used as the reference category to predict the chance of minor or severe abuse received by women. Since the dependent variable has three categories, present study used multinomial logistic regression technique to determine unique predictors of wife abuse.

Table 4 presents the B, Standard Error, as well as Wald, Exp (B) or Odds Ratio (OR), and 95\% Confidence interval around the estimated OR. According to Table 4, neuroticism [B=.063, OR=1.065 (95\% CI 1.009 to 1.123, $p=.02)$ ] significantly predicted minor abuse than non-abuse among respondents. The OR for neuroticism shows that one unit increase in neuroticism among women increases $6.5 \%(1-1.065 \times 100)$ of their chance to experience minor abuse. In other word, the OR of neuroticism who got minor abuse was about 1.06 than non-abused.

Neuroticism also significantly predicted severe abuse than non-abuse $[(\mathrm{B}=.092, \mathrm{OR}=1.096(95 \%$ CI 1.036 to $1.161, p=.00)]$. Thus, with one unit increase in neuroticism among women, their chance to experience severe abuse 
increases up to $9.6 \%$ of. It means the OR of neuroticism among the group who experienced severe abuse was 1.096 than the non-abuse group.

Table 4. Results of multinomial logistic regression on severity of total wife abuse

\begin{tabular}{|c|c|c|c|c|c|c|c|c|}
\hline \multirow{2}{*}{ Variable } & \multirow{2}{*}{$\mathbf{B}$} & \multirow{2}{*}{ SE } & \multirow{2}{*}{ Wald } & \multirow{2}{*}{ df } & \multirow{2}{*}{ Sig. } & \multirow{2}{*}{$\operatorname{Exp}(B)$} & \multicolumn{2}{|c|}{ 95\% Confidence Interval for $\operatorname{Exp}(B)$} \\
\hline & & & & & & & Lower Bound & Upper Bound \\
\hline \multicolumn{9}{|l|}{ Minor abuse } \\
\hline Intercept & -1.16 & 2.67 & .189 & 1 & .66 & & & \\
\hline Neuroticism & .063 & .027 & 5.321 & 1 & .02 & 1.065 & 1.009 & 1.123 \\
\hline Extraversion & -.014 & .034 & .170 & 1 & .68 & .986 & .922 & 1.054 \\
\hline Openness & .027 & .038 & .521 & 1 & .47 & 1.028 & .954 & 1.107 \\
\hline Agreeableness & .053 & .036 & 2.121 & 1 & .14 & 1.054 & .982 & 1.132 \\
\hline Conscientiousness & -.006 & .032 & .039 & 1 & .84 & .994 & .933 & 1.059 \\
\hline \multicolumn{9}{|l|}{ Severe abuse } \\
\hline Intercept & 1.062 & 2.81 & .142 & 1 & .70 & & & \\
\hline Neuroticism & .092 & .029 & 9.990 & 1 & .00 & 1.096 & 1.036 & 1.161 \\
\hline Extraversion & -.019 & .037 & .266 & 1 & .60 & .981 & .913 & 1.054 \\
\hline Openness & .028 & .040 & .490 & 1 & .48 & 1.028 & .951 & 1.111 \\
\hline Agreeableness & .029 & .038 & .569 & 1 & .45 & 1.029 & .955 & 1.108 \\
\hline Conscientiousness & -.014 & .033 & .181 & 1 & .67 & .986 & .923 & 1.053 \\
\hline
\end{tabular}

\section{Conclusion}

This study found a significant positive relationship between neuroticism personality trait and severity of total wife abuse. Studies by Burton et al. (2007) and Rampersad (2008) also showed significant relationship between high level of aggression and neuroticism. Panaghi et al. (2011) found a significant relationship between neuroticism and wife abuse. Women with neuroticism personality trait may receive more severe abuse by the husbands. Individual with neuroticism personality trait is usually moody, anxious, and emotionally not stable (Garusifarshi, 1998). So, wife with more neuroticism personality might not be able to do her duty well and may be subjected to more abuse by husband. The results also showed significant negative relationship between extraversion and severity of total wife abuse. The finding is consistent with Burton et al. (2007) who found that respondents with high level of extraversion tend to be less abuse. Women with extraversion personality have characteristics such as sociable, assertive, active, exuberant, excitement seeking, sexual arousal, cheerful, optimism and talkative (Atashrouz, Askeri, \& Pakdaman, 2008). Wife with these characteristics may establish close relationships with the husband and may influence husband to be more gentle and kind to her; and consequently reduced husband's tendency to be abusive.

This study found a significant negative relationship between agreeableness personality trait and severity of total wife abuse. This finding strengthened previous study by Burton et al. (2007). Respondents who had high score of agreeableness personality trait received less severe abuse. Agreeableness refers to a continuum from compassion to antagonism and the quality of social interaction with others. Women with this type of personality tend to be warm, considerable, kind, and cooperative (Thompson, 2008) and these characteristics may mellow down husband's aggressive instincts. Significant negative relationship found between conscientiousness personality and severity of total wife abuse. Women with high conscientiousness personality may receive less severe abuse. Women who are conscientious are more organized, thoughtful and have higher control on their impulses (Garusifarshi, 1998). So, she can analysis her husband abusive behavior and chooses best strategy to control her and her husband behavior to decrease the wife abuse. Multinomial logistic regression showed that neuroticism is a significant predictor of minor and severe wife abuse. Previous study by Hines and Saudino (2008) and Panaghi et al. (2011) also found neuroticism as the strongest predictor of family abuse particularly for women.

The findings of this study have important implications for theoretical perspective that address the relationships 
between personality traits and severity of wife abuse. This study provides evidence for Heise ecological perspective (1998). Personality is one of the factor of personal layer of ecological perspective. Personal layer affects person's behavior. So, personality traits influence woman's behavior and act and determine to what extent they will be subjected to abuse by the husbands. The present finding also support trait personality theory that explains how personality traits affect abuse.

Based on the result of the current study, type and level of personality has significant relationship with severity of wife abuse among women in Tehran-Iran. Women who are more neurotic, less extraversion, less agreeable and less conscientious are more likely to receive severe wife abuse. Thus, it is recommended that women in Iran be educated to understand their own personality. So they can control their behavior in close relationship in order to minimize the possibility of being abuse. The information obtained in the present study has important implications to the Ministry of Health, Welfare Organization and family consulting centers of Iran to better understand the factors which have strong influence on severity of wife abuse.

Although it is difficult to change the type of personality, but woman can decreases severity of abuse by some strategy. At first women should be careful about their marriage. Because type of personality of man and woman effects on their conflict. For example, if woman and man have less score of extraversion, it is difficult for them to cope. Also, woman should know about her and her husband personality, and meet counselor to get guidance.

Family and parents should know about personality of their girl and try to help them to marry with appropriate personality person, because some man and women are not appropriate for each other to marry based on the types of personality.

Administration and policy makers should have programs such as workshops, movies on TV, or information through newspapers about the women who are more neuroticism, or less exterior, agreeable, and conscientious. They can inform couples to know their personality, and give information to women and men to choose best strategies against this issue. Administration and policy maker should make plans for neurotic wife to treat them. So, neurotic women can do their duty in family and conflict will decrease and finally wife abuse may decrease.

\section{Acknowledgment}

Researchers of this study wish to thank staff of the hospitals that helped us a lot during data gathering.

\section{References}

Alio, A. P., Nana, P. N., \& Salihu, H. M. (2009). Spousal violence and potentially preventable single and recurrent spontaneous fetal loss in an African setting: Cross-sectional study. The Lancet, 373(9660), 318-324. http://dx.doi.org/10.1016/S0140-6736(09)60096-9

Atashrouz, B., Askeri, A., \& Pakdaman, S. (2008). Personality and success of study. Journal of Iranian Psychologists, 16, 77-86.

Belfrage, H., \& Rying, M. (2004). Characteristics of spousal homicide perpetrators: A study of all cases of spousal homicide in Sweden 1990-1999. Crim Behav Ment Health, 14(2), 121-133. http://dx.doi.org/10.1002/cbm.577

Bengtson, V. L., Acock, A. C., Allen, K. R., Anderson, P. D., \& Klein, D. M. (2005). Sourcebook of family theory and research. London: SAGE.

Burton, L. A., Hafetz, J., \& Henninger, D. (2007). Gender differences in relational and physical. Social Behavior and Personality, 35(1), 41-50. http://dx.doi.org/10.2224/sbp.2007.35.1.41

Clark, L. A., Vittengl, R., Kraft, D., \& Jarrett, R. B. (2003). Shared, not unique, components of personality and psychosocial functioning predict depression severity after acute-phase cognitive therapy. Journal of Personality Disorders, 17(5), 406-430. http://dx.doi.org/10.1521/pedi.17.5.406.22975

Crandall, M., Schwab, J., Sheehan, K., \& Esposito, T. (2009). Illinois trauma centers and intimate partner violence. Journal of Interpersonal Violence, 24(12), 2096-2108. http://dx.doi.org/10.1177/0886260508327702

Ezazi, S. (2002). Battered women. Tehran: Sali.

Fakhari, A., Shahedifar, N., Mohamadpourasl, A., \& Ghazitabatabayi, S. M. (2011). Severe physical wife abuse and confidence. Psychological Journal, 329-330.

Ferris, L. E., McMain, K. M., \& Silver, L. (1997). Documenting wife abuse: A guide for physicians. Canadian Medical Association, 126, 1015-1022. 
Garousifarshi, M. T., \& Soufiyani, H. (2008). Relationship between health and personality of student. Journal of Ferdosi University, 47-63.

Garusifarshi, M. T. (1998). Standardization of the NEO-PI-R. MS thesis. Tehran: Tarbiat Modarres University.

Ghazitabatabayi, M., Mohsenitabrizi, A. R., \& Marjayi, S. H. (2005). Wife abuse in Iran (A national study in Iran). Tehran: Ministry of Interior.

Hampton, R. L., \& Gullotta, T. P. (1993). Family violence. California: SAGE.

Hayes, N., \& Joseph, S. (2003). Big 5 correlates of three measures of subjective well-being. Personality and Individual Differences 34, 723-727. http://dx.doi.org/10.1016/S0191-8869(02)00057-0

Hegarty, K., Hindmarsh, E. D., \& Gelles, M. T. (2000). Violence in Australia: Definition, prevalence and nature of presentation in clinical practice. MJA, 173, 363-367.

Heise, L. L. (1998). Violence against women: An integrated, ecological framework. Violence Against Women, 4(3), 262-290. http://dx.doi.org/10.1177/1077801298004003002

Hemati, R. (2005). Factors affecting violence against women. Journal of Social Welfare Research, 12, 23-32.

Hines, D. A., \& Saudino, K. J. (2008). Personality and intimate partner aggression in dating relationships: The role of the "Big Five". Aggressive Behavior, 34(6), 593-604. http://dx.doi.org/10.1002/ab.20277

John, O. P., \& Srivastava, S. (1999). The big five trait taxomony: History, measurment, and theoretical perpectives. Berkly: University of California.

Kaldi, A., Hajibabayi, F., \& Kianfard, M. (2005). Why some kill partner. Social Science Journal, 9, 20-29.

Kassin, S. (2003). Psychology. U.S.A: Prentice-Hall, Inc.

Kyu, N., \& Kania, A. (2005). Prevalence, antecedent causes and consequences of domestic violence in Myanmar. Asian Journal of Psychology, 8, 244-271. http://dx.doi.org/10.1111/j.1467-839X.2005.00170.x

Ludermir, A. B., Schraiber, L. B., D'Oliveira, A. F., Junior, F., \& Jansen, H. A. (2008). Violence against women by their intimate partner and common mental disorders. Soc Sci Med., 66(4), 1008-1018. http://dx.doi.org/10.1016/j.socscimed.2007.10.021

McCrae, R. R., \& Costa, P. T. (1987). Validation of the Five-Factor Model of Personality across instruments and observers. Journal of Personality and Social Psychology, 52(1), 81-90. http://dx.doi.org/10.1037/0022-3514.52.1.81

Mignon, S. I., Larson, C. J., \& Holmaes, W. (2002). Family abuse. Boston: Allyn and Bacon.

Mischel, Y., Shoda, Y., \& Smith, R. E. (2003). Introduction to personality toward an integration. New York: John Wiley and Sons, INC.

Nagae, M., \& Dancy, B. L. (2010). Japanese women's perceptions of intimate partner violence (IPV). Journal of Interpersonal Violence, 25, 753-766. http://dx.doi.org/10.1177/0886260509334413

Narimani, M., \& Aghamohamadian, H. R. (2005). Rate of abuse against wife in Ardebil-Iran. The Quarterly Journal of Fundamentals of Mental Health, 7, 107-113.

Nohjah et al. (2011). Rate and factors of wife abuse in Khouzestan state. Journal of Medical Kermanshah University, 14, 278-286.

Oladeji, D., \& Adegoke, T. (2008). Personal, situational and socio-cultural factors as correlates of intimates partner abuse in Nigeria. $J$ Soc Sci, 16, 57-62.

Panaghi, L., Pirouzi, D., Shirinbayan, M., \& Ahmadabadi, Z. (2011). The role of personality and demographic traits in spouse abuse. Iranian Journal of Psychiatry and Clinical Psychology, 17(2), 126-135.

Pournaghashtehrani, S. S. (2006). Violence among families in Tehran-Iran. Journal of Shahed University, 13, 23-36.

Rampersad, D. N. (2008). The role of coping resources and neuroticism in predicting female aggression in intimate relationship. Doctoral thesis, Georgia State University, Atlanta, United States.

Records, K. (2007). A critical review of maternal abuse and infant outcomes: Implications for newborn nurses. Newborn and Infant Nursing Reviews, 7(1), 7-13. http://dx.doi.org/10.1053/j.nainr.2006.12.005

Ruikar, M. M., \& Pratinidhi, A. K. (2008). Physical wife abuse in an urban slum of Pune, Maharastra. Indian Journal of Public Health, 52(4), 215. 
Setarefrouzan, A., Dejman, M., \& Baradaraneftekhari, M. (2006). Cost of wife abuse in Tehran legal medicine centers. Payesh, 3, 201-206.

Sharma, L. A. (2011). Personality and intimate partner aggression in Gorakhpur, Uttar Pradesh, India, Doctoral thesis, University of Iowa, Iowa, U. S. A.

Shoultes, D. (2008). Theories of personality (S. Y. Mohamadi, Trans.). Tehran: Nashre Virayesh.

Sinha, M. (2012, May 22). Family violence in Canada: A statistical profile 2010. Authority of the Minister responsible for Statistics Canada, Canada.

Straus, M. A., \& Douglas, E. M. (2004). A short form of the revised conflict tactics scales, and typologies for severity and mutuality. Violence and Victims, 19, 507-521. http://dx.doi.org/10.1891/vivi.19.5.507.63686

Straus, M. A., Hamby, S. L., Boney-McCoy, S., \& Sugmarman, D. B. (1996). The revised conflict tactics scales (CTS2): Development and preliminary psychometric data. Journal of Family Issues, 17(3), 283-316. http://dx.doi.org/10.1177/019251396017003001

Straus, M., Hamby, S. L., \& Warren, W. L. (2003). The canflict tactics scales handbook. Los Angeles: Western Psycological Services WPS.

Talbot, N., Duberstein, P. R., King, D. A., Cox, C., \& Giles, D. E. (2000). Personality traits of women with a history of childhood sexual abuse. Comprehensive Psychiatry, 41(2), 130-136. http://dx.doi.org/10.1016/S0010-440X(00)90146-9

Thabet, A. A., Tawahina, A. A., Sarraj, E. E., \& Vostanis, P. (2011). Evaluation of a community intervention for women victims of domestic violence in the Gaza strip. International Journal of Peace and Development Studies, 2(3), 88-95.

Thompson, E. R. (2008). Development and validation of an international English Big-Five mini-markers. Personality and Individual Differences, 45, 542-548. http://dx.doi.org/10.1016/j.paid.2008.06.013

Tokuc, B., Ekuklu, G., \& Avcioglu, S. (2010). Domestic Violence Against Married Women in Edirne. Interpersonal Violence, 25(5), 832-847. http://dx.doi.org/10.1177/0886260509336960

Walby, S., \& Allen, J. (2004). Domestic violence, sexual assault and stalking: Findings from the British Crime Survey. London: Home Office Research, Development and Statistics Directorate.

Wiehe, R. V. (1998). Underestanding family violence. California: SAGE.

\section{Copyrights}

Copyright for this article is retained by the author(s), with first publication rights granted to the journal.

This is an open-access article distributed under the terms and conditions of the Creative Commons Attribution license (http://creativecommons.org/licenses/by/3.0/). 